\title{
Deskripsi Dan Habitat Mycalesis Perseus Fabricius, 1775 (Rhopalocera: Nymphalidae) Spesies Kosmopolitan Di Gunung Tompotika, Sulawesi
}

\section{Description And Habitat Of Mycalesis Perseus Fabricius, 1775 (Rhopalocera: Nymphalidae) Kosmopolitan Species In Mt. Tompotika, Sulawesi}

\author{
Cipta Afrilianti ${ }^{{ }^{*}}$, Mihwan Sataral ${ }^{2}$, Elijonnahdi ${ }^{3}$, F. Fahri ${ }^{1}$ \\ ${ }^{1}$ Laboratorium Biosistematika Hewan dan Evolusi, Jurusan Biologi, Fakultas MIPA, Universitas Tadulako, JI. Soekarno \\ Hatta km 9 Tondo, Palu 94118, Sulawesi Tengah, Indonesia. \\ ${ }^{2}$ Program Studi Agroteknologi, Fakultas Pertanian, Universitas Tompotika, Luwuk 94715, Sulawesi Tengah, Indonesia. \\ ${ }^{3}$ Program Studi Pendidikan Biologi, STKIP Abdi Pendidikan Payakumbuh, Padang Sumatera Barat 26252, Indonesia.
}

Keywords: Mycalesis perseus, Description, habitat, Mt.

Tompotika, Sulawesi.

Keywords: Mycalesis perseus, Deskripsi, Habitat, Gunung Tompotika, Sulawesi.

* Coresponding Author : Ciptaafrilianti@gmail.com

\begin{abstract}
This study aims to describe Mycalesis perseus Fabricius, 1775 and learn its habitat in Mt. Tompotika, Sulawesi. This research was conducted in February-March 2019. The butterflies was collected by using purposive sampling method with sweeping techniques using insect net along the hiking trails. The character of M. perseus is explained by the head, thorax, abdomen and wings. Mycalesis perseus characterized by ocellion the wing which borders with the white line on the postdiscal forewing and hindwing sections. Mycalesis perseus was found in secondary forest habitats and cashew gardens at an altitude of 100-200 meters above sea level.
\end{abstract}

\begin{abstract}
Abstrak
Penelitian ini bertujuan untuk mendeskripsi Mycalesis perseus Fabricius, 1775 dan mempelajari habitatnya di gunung Tompotika, Sulawesi. Penelitian ini dilaksanakan pada bulan Februari-Maret 2019. Kupu-kupu dikoleksi menggunakan metode purposive sampling dengan teknik sweeping menggunakan jaring serangga di sepanjang jalur pendakian. Karakter M. perseus dijelaskan mulai dari head, thorax, abdomen dan wings. Mycalesis perseus dicirikan dengan adanya ocelli pada sayap yang berbatasan dengan garis putih pada postdiscal bagian forewing dan hindwing. Spesies ini ditemukan pada habitat hutan sekunder dan kebun mente pada ketinggian 100-200 meter di atas permukaan laut.
\end{abstract}

\section{Latar Belakang}

Mycalesis adalah salah satu genus besar yang terdiri dari 100 spesies atau lebih, tujuh spesies ditemukan di Sulawesi (Vane-Wright and de Jong, 2003). Genus ini pertama kali dideskripsi oleh Hubner pada tahun 1818. Salah satu spesies dari genus ini yang ditemukan di Sulawesi adalah $M$. perseus. Mycalesis perseus merupakan salah satu spesies dari family Nymphalidae. Spesies ini dideskripsi pertamakali oleh Fabricius pada tahun 1775. Berbagai macam habitat yang disukai oleh spesies ini terutama hutan dataran rendah sabana dan hutan terbuka eukaliptus dengan tumbuhan bawah yang berumput (Braby, 2004). Spesies ini sangat umum dan terdistrusi 
secara luas (Braby, 2004). Distribusi M. perseus mulai dari Sri Lanka, India, China, Burma, Australia utara, Semenanjung Melayu, Sumatra, Jawa, Kepulauan sunda kecil, Borneo, Palawan, Filipina, Maluku, Papua Nugini, Pulau Solomon dan Sulawesi (Vane-Wright and de Jong, 2003).

Sulawesi merupakan salah satu pulau yang memiliki spesies terbanyak kupu-kupu setelah Jawa, Sumatera dan Kalimantan (Peggie, 2014). Sekitar 557 spesies dengan endemisitas tertinggi berada di Pulau ini (Vane-Wright and de Jong, 2003). Gunung Tompotika merupakan gunung yang memiliki tipe hutan pegunungan bawah dengan ketinggian sekitar 1.530 mdpl. Gunung Tompotika terdapat di Kabupaten Banggai dan hingga saat ini tidak banyak data mengenai fauna di Gunung ini kecuali Kodok Dicroglossidae (Iskandar et al., 2011). Penelitian ini bertujuan untuk mengetahui dan memberikan informasi terbaru mengenai deskripsi dan habitat Mycalesis perseus (Rhopalocera: Nymphalidae) spesies kosmopolitan di gunung tompotika, Sulawesi. Dengan data tersebut, akan lebih mudah untuk mengenali spesies dan habitat yang sesuai bagi spesies kosmopolitan M. perseus.

\section{Bahan dan Metode}

Penelitian ini dilaksanakan pada bulan FebruariMaret 2019 di Gunung Tompotika. Lokasi pengambilan sampel dilakukan pada dua tipe habitat yaitu Kebun Mente yang terletak pada koordinat S 00³7'47.60" E 12307'39.60" dan Hutan Sekunder pada koordinat S 003'01.60" E 1230'ㄴ.48".

Koleksi sampel kupu-kupu dilakukan dengan metode purposive sampling. Kupu-kupu dikoleksi dengan teknik sweeping menggunakan insect net (jaring serangga) di sepanjang jalur pendakian. Pengambilan sampel dimulai pukul 07.00-17.00 WITA. Kupu-kupu dimatikan dengan memencet bagian dada (thorax) kemudian disimpan dalam kertas papilot.

Setelah koleksi, sampel dibawa ke Laboratorium Biosistematika Hewan dan Evolusi Hewan Jurusan Biologi, Fakultas Matematika dan Ilmu Pengetahuan Alam, Universitas Tadulako untuk proses pengawetan dan identifikasi. Sampel kupu-kupu dipinning dan dimounting sesuai standar museum. Identifikasi sampel kupu-kupu menggunakan panduan identifikasi Vane-Wright et al., (2003), Peggie (2014) dan Braby (2004). Deskripsi Mycalesis perseus dijelaskan dalam bentuk diagnosis mulai dari kepala, thoraks, perut dan sayap.

\section{Hasil dan Pembahasan}

Mycalesis perseus yang didapatkan dengan jumlah total 4 individu, yang berasal dari habitat hutan sekunder (3 individu) dan kebun mente (1 individu).

\section{Karakter Mycalesis perseus Fabricius, 1775:}

Head: Mata berwarna cokelat, palpi berwarna cokelat dengan warna putih pada bagian lateral. Antena berwarna cokelat.

Thorax: berwarna cokelat.

Abdomen: berwarna cokelat.
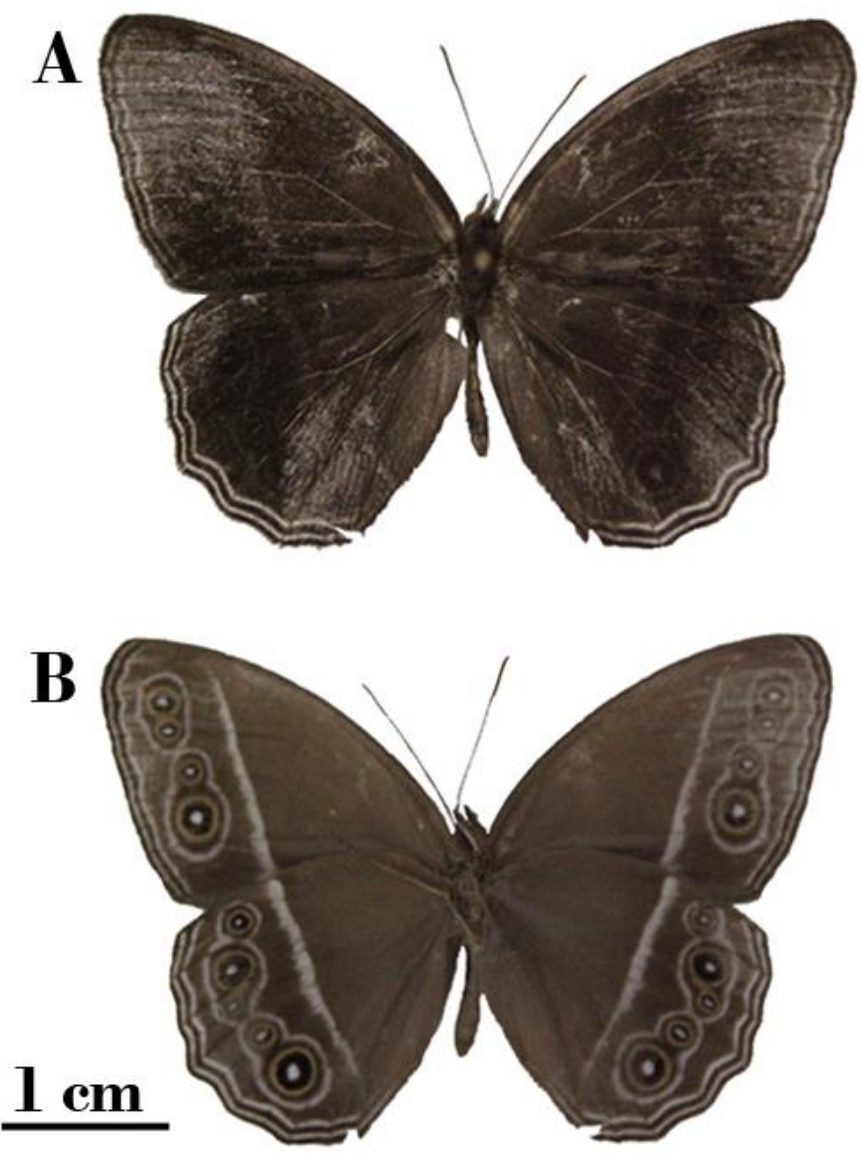

Gambar 1. Mycalesis perseus Fabricius, 1775, A). Dorsal dan B). Ventral

Wings: Rentang sayap 4,2-4,5 cm dan panjang sayap 2-2,2 cm $(n=4)$. Dorsal; forewing dan hindwing berwarna cokelat-gelap hingga pucat. Disepanjang hindwing bagian tornus, termen sampai apex dengan garis berwarna putih. Ventral; forewing dan hindwing memiliki warna yang sama seperti dorsal. 


\section{Deskripsi Habitat:}

Mycalesis perseus ditemukan pada habitat hutan sekunder. Hutan sekunder merupakan kawasan hutan alami tetapi telah terjadi kerusakan atau perubahan dari kondisi hutan sebelumnya. Kawasan hutan sekunder terletak pada ketinggian $182 \mathrm{~m}$ dpl. Pada habitat tersebut terdapat vegetasi tumbuhan herba yang diduga sebagai pakan kupu-kupu $M$. perseus baik pada saat larva maupun imago. Menurut VaneWright and de Jong (2003), pakan kupu-kupu imago berasal dari tumbuhan herba family Poaceae. Pada habitat ini juga terdapat sungai yang merupakan sumber air dan menjadi salah satu faktor penunjang hidup kupu-kupu.



Gambar 2. Habitat Mycalesis perseus. A) Hutan Sekunder, B) Kebun Mente.

Selain hutan sekunder, kupu-kupu ini juga ditemukan pada habitat kebun mente. Kebun mente terletak pada ketinggian $148 \mathrm{~m}$ dpl dengan luas areal sekitar 20 ha. Pada habitat tersebut didominasi oleh tumbuhan mente (Anacardium occidentale L.). Selain tumbuhan mente ( $A$. occidentale $\mathrm{L})$, juga 
terdapat vegetasi tumbuhan bawah. Selain itu, terdapat sumber air yang menjadi salah satu faktor penunjang hidup kupu-kupu (Gambar 2).

Menurut Braby (2004), kupu-kupu jenis Mycalesis perseus ditemukan pada habitat hutan dataran rendah sabana \& hutan terbuka eukaliptus dengan tumbuhan bawah yang berumput dari Australia. Mycalesis perseus juga ditemukan pada ketinggian rendah di Himalaya dari Kulu ke Sikhim (Bingham, 1905).

\section{Ucapan Terima Kasih}

Penulis mengucapkan terima kasih kepada Bapak Munawir Kunjae sebagai Kepala Desa Sampaka yang telah memberikan izin untuk pengambilan sampel di kebun mente. Kepada tim: Jusman, Muh. Sucipto Suharman, Reza Rizaldi, Hartina, Zarina Djusman, Fadli Djawaba, Zikry Nurdiansyah, dan Armaludin Embikarim yang telah membantu koleksi sampel selama penelitian di lapangan. Penelitian ini didukung oleh dana dari hibah "Penelitian Kerja Sama Antar Perguruan Tinggi" antara Universitas Tadulako dan Institut Pertanian Bogor, yang diberikan oleh
Kementerian Riset Teknologi dan Pendidikan Tinggi (Indonesia) kepada Fahri, S.Si., M.Si.

\section{Daftar Pustaka}

Bingham, C.T. (1905). The Fauna of British India, Including Ceylon and Burma Butterflies (pp 59). Vol.1 (1st ed.). London: Taylor and Francis, Ltd.

Braby, M. F. (2004). The Complete Field Guide to Butterflies of Australia (pp 152). Australia: Stanford University.

Iskandar, D. T., Arifin, U., and Rachmansah, A. (2011). A New Frog (Anura, Dicroglossidae), Related to Occidozyga semipalmata SMITH, 1927, From The Eastern Peninsula of Sulawesi, Indonesia, The Raffles Bulletin of Zoology, 59(2): 219-228.

Peggie, D. (2014). Mengenal Kupu-Kupu (hal 1-79). Bogor: Pandu Aksara Publishing.

Vane-Wright, R. I., and de Jong, R. (2003). The butterflies of Sulawesi: annotated checklist for critical island fauna. Zoologische Verhandelingen, 343: 1-268. 